\title{
Economic valuation of the Danau Sentarum National Park, West Kalimantan, Indonesia
}

\author{
EMI ROSLINDA \\ Faculty of Forestry, Universitas Tanjungpura. Jl. Imam Bonjol, Pontianak 78124, West Kalimantan, Indonesia. \\ Tel.: +62-561-765342, `email: eroslinda71@gmail.com.
}

Manuscript received: 14 May 2019. Revision accepted: 27 June 2019.

\begin{abstract}
Authors. 2019. Economic valuation of the Danau Sentarum National Park, West Kalimantan, Indonesia. Biodiversitas 20: 1983-1989. The Danau Sentarum ecosystem in West Kalimantan, Indonesia is officially protected by its status as an Indonesian national park. Nevertheless, it remains under severe threat of deforestation. Rainforest destruction has already caused a decline in ecosystem functions and services. In addition, it is affecting numerous economic activities in and around the Danau Sentarum National Park. The objectives of this study are to determine the total economic value (TEV) of the Danau Sentarum National Park and look for appropriate mechanisms to realize such values. Survey methods were used in this research. 180 respondents were selected by random sampling method from three Management Section National Park (MSNP). TEV in this research was restricted on direct use value, indirect use value and option value. Estimation of DSNP ecosystem benefits was approached by market price, travel cost method, contingent valuation method, and opportunity cost adjusted for the benefits calculated. The direct use value of Danau Sentarum National Park is IDR 18.5 billion/year while the indirect use value of Danau Sentarum National Park is IDR 34.2 billion/year. The option value of Danau Sentarum National park is IDR 86.2 billion/year. The total economic value resulted in Danau Sentarum National Park is IDR 139,1 billion/year, equivalent to an average of IDR 1.1 million/year for the total park area (132,000 ha). When compared to the TEV of the DSNP, such costs amounted to only 4.87 percent compared to the value of the benefits Based on monetary values of ecosystem services that are provided by this park we could assess the mechanisms to finance the park's conservation and sustainable use. This will help the self-management of national parks.
\end{abstract}

Keywords: Ecosystem services, management, national parks, total economic value, valuation

\section{INTRODUCTION}

Danau Sentarum National Park (DSNP) in West Kalimantan (Indonesia) covers 132,00 ha and consists of a core area, which is a series of interconnected seasonal lakes (of some 82,000 ha), with surrounding hillier dryland areas. (Figure 1). It is located on the northern side of the Kapuas River, $700 \mathrm{~km}$ upriver from Pontianak, capital city of West Kalimantan. Deforestation in this area is widespread, despite its formally protected status (Heri et al. 2010; DSNP 2011). This is believed to have severe ecological consequences, such as the probable local extinction of endemic species such as orangutans, proboscis monkeys, some fish, and other species. In addition, the local economy could become structurally damaged as crucial ecological functions of the rainforest decline. Consequent damage caused by floods, erosion, and loss of water supply can greatly exceed the revenues derived from timber extraction and land conversion.

The DSNP provides important habitat to many wild and animals and plants. To measure the importance of this service, the (ecological) value was determined based on diversity, uniqueness, and integrity. (i) Diversity: The DSNP has a high diversity of ecosystems and is a key area for conservation in Kalimantan. The predominant vegetation is swamp forest, and more than 500 species of plants have been identified (Giesen 2000). The forest is flooded for much of the year by seasonal lakes whose water levels can vary by up to 12 meters; these lakes support a high diversity of fish, some 211 species (Kottelat and Widjanarti 2005). Reptilian and amphibian fauna include crocodiles (Frazier 2000), turtles (Walter 2000), monitor lizards and snakes. The number of bird species is 237 (van Balen and Dennis 2000). With the exception of proboscis monkeys (Sebastian and Dennis 2000) and orangutans (Russon et al. 2001), information on mammals is limited. Danau Sentarum hosts many species not found, or rarely found, elsewhere because of its underlying hydrology and the relatively good condition of the habitats (Aglionby 2010). (ii) Uniqueness: There is a significant amount of endemic species in The DSNP with $78 \%$ of endemic freshwater fish species, one species of endemic reptiles, 5 species of endemic birds, 26 species of mammals, 59 genera of endemic plants (Giesen 1987), and 30-34 species of endemic watergrass (Giesen and Agloinby 2000). The DSNP also provides habitat to endangered species such as orangutans. (iii) Integrity: Most of the DSNP is a series of interconnected seasonal lakes (about 82,000 ha) with a surrounding area of dry land.

There are two major rivers in the DSNP which flow into the Kapuas river and interconnect with seasonal lakes. The abundance of lakes in this park is due to very high precipitation; the DSNP is known as being one of the rainiest places in Kapuas Hulu Regency (the mean annual rainfall in the Danau Sentarum is $3,900 \mathrm{~mm}$ ), while the surrounding hills and mountains of the catchment area 
receives 4,500-6,000 $\mathrm{mm}$ per year (Aglionby 2000). The DSNP is a key place for water supply as it provides water for West Kalimantan, and has a potential for hydroelectricity (Indriatmoko 2010). The lakes act as a buffer for the Kapuas River system, flood control and water level buffer in the dry season. According to the model developed by Klepper (1994), a quarter of the Kapuas River flood peak upstream is sucked into DSNP and swamp forests, thereby significantly reducing downstream flooding. During the dry season, up to $50 \%$ of the water in the upper Kapuas River consists of water flowing from the lake and swamp forest, so as to maintain the water level and keep the downstream water supply constant throughout the year (Aglionby 2000).

The area for public recreational use is only $1 \%$ of the park and is located in the so-called "Tekenang Hills" of the National Park, and at another site. It contains three entry points and is called: Lanjak, Semitau and Selimbau gate. Visitor numbers are low compared to the most visited national parks of Indonesia. This is because of the location, accommodation capacity and management capacity of the DSNP. If the management capacity was increased by the development of better infrastructure, equipment and personnel the park could receive more visitors.

The economic valuation of natural resources can be defined as the study of allocation of natural resources like water, land, fish, and forest (Fauzi 2004). Benefits which could be provided by natural resources to meet human needs are numerous, but limitations in science and technology, as well as rigid institutional arrangement, have impeded types and amount of its utilization so that benefits obtained are still very low (Darusman 2012). The selection of the appropriate environmental management alternatives is complex compared to the options available in the private sector (Harahap 2010). The objective of the valuation of ecosystem services is to indicate generally the overall economic efficiency of the various competing uses of the functions of a particular ecosystem. The underlying assumption is that ecosystem resources should be allocated to those uses that yield an overall net gain to the society, as measured through valuation regarding the economic benefit of each use adjusted by its costs (Kumar and Kumar 2008).

The objectives of this study are to determine the total economic value (TEV) of the DSNP and look for appropriate mechanisms to realize such values.

\section{MATERIALS AND METHODS}

\section{Study area}

This study was conducted in Danau Sentarum National Park (DSNP) that is the $2^{\text {nd }}$ Ramsar Site in Kapuas Hulu District, West Kalimantan Province, Indonesia. DSNP is an area of freshwater lakes and lowland swamp forest. DSNP was established in 1985 as the Danau Sentarum Wildlife Reserve (Giesen and Aglionby 2000), and became a national park in 1995 (Wadley et al. 2010) and on 4 February 1999 by decree of the Minister of Forestry Number 34/Kpts-II/1999. This area includes the 132,000 ha. which has natural beauty, high biodiversity, traditional fishery as well as local people's culture. All of the above are characteristics that can be managed sustainably for the benefit of the community.

The administration of this region covers the district of Kapuas Hulu District and includes seven sub-districts: Batang Lupar, Badau, Embau, Bunut Hulu, Suhaid, Selimbau, and Semitau. To manage this area, the DSNP is divided into three sections called Management Section National Park (MSNP) namely MSNP I Lanjak, MSNP II Semitau, and MSNP III Selimbau (DSNP 2011), which can be seen in Figure 1. The villages in DSNP are famous for their fishery resources management systems, as well as their distinctive forestry and agriculture (Harwell 1997; Wadley 1997; Colfer et al. 2000; Dudley 2000; Yasmi et al. 2010).

\section{Procedures}

The research was carried out by surveying the inhabitants of the designated areas. These surveys were then analyzed quantitatively using the case study method. The case study method provides broad access and gives opportunities for researchers to examine the social unit. indepth, in detail, intensively and thoroughly. The case study can provide useful data. Findings become the basis for building the background issues for planning larger in-depth studies, in order to develop knowledge.

Data and information collection were conducted by interviewing respondents using structured questionnaires. The respondents were randomly selected from the residents of the three STPN with the total number of respondents was 180 (every MSNP were 60 respondents). Selection of sample village and respondents were done randomly based on benefit of DSNP felt and got by people directly or indirectly. Some questions asked to respondents directly include the kind of products and services they attained. Field observation was conducted for three months.

\section{Data analysis}

The analysis of economic value was carried out as follows: (i) Identify types of DSNP ecosystem benefits descriptively. (ii) Biophysical assessment/quantification including type, location and scale, system and model of utilization. (iii) Value classification. Analysis of total economic value of DSNP ecosystem was conducted by using formula from Munasinghe (1993) as follows:

$$
\mathrm{TEV}=(\mathrm{DUV}+\mathrm{IUV}+\mathrm{OV})
$$

Where :

$$
\begin{aligned}
& \text { TEV = Total economic value } \\
& \text { DUV = Direct use value } \\
& \text { IUV = Indirect use value } \\
& \text { OV = Option value }
\end{aligned}
$$

\section{Direct use value (DUV)}

The immediate benefits are benefits derived from land use associated with DSNP ecosystem based on market prices and opportunity cost including fish, honey, rubber, rice, fuelwood. Estimation of DSNP ecosystem benefit as recreation was approached by travel cost method. 

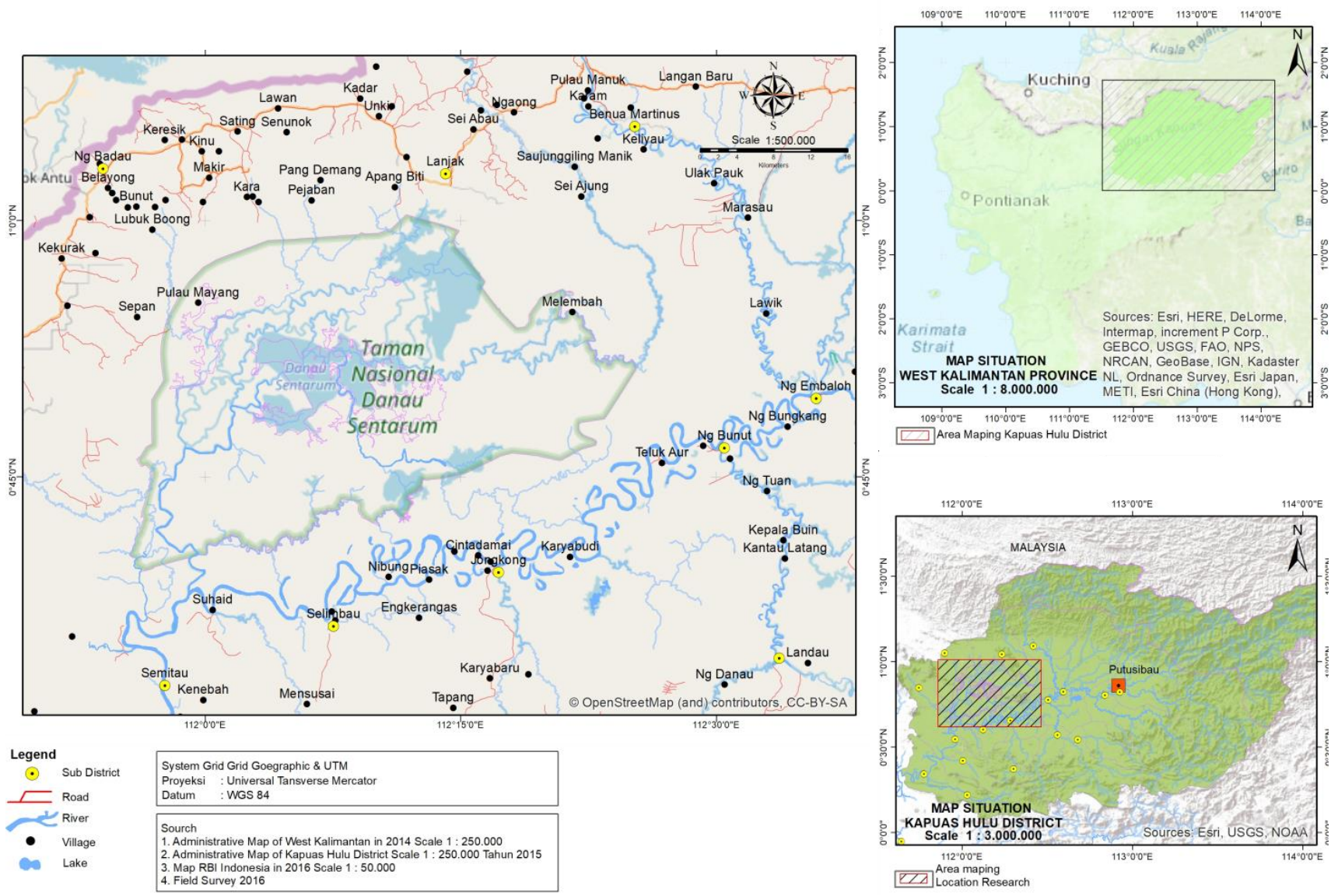

Figure 1. Map of management section of Danau Sentarum National Park, Kapuas Hulu District, West Kalimantan Province, Indonesia (Source: DSNP 2011)

\section{Indirect use value (IUV)}

Indirect use value is the sum of indirect benefits gained from DSNP ecosystem including water for household, water for transportation, water for fisheries and carbon sink. In this study, indirect benefits are limited to its function as mention before. Estimation of DSNP ecosystem benefits as water for household was approached from water consumption costs to be incurred based on standard water needs of average household issued by Putussibau Regional Water Enterprise. While estimation of its function as water for transportation was approached by means of the cost for local fuel price. Estimation of its function as water for fisheries was approached by market price.

Calculation of DSNP ecosystem function as carbon sink was estimated from market price and from previous several studies on carbon biomass of DSNP. This determination refers to the UNFCC carbon value payment scheme in peat swamp forest. Estimation of carbon value use the formula as follows :

$\mathrm{NSc}=(\{\operatorname{Lg} \times \mathrm{Kcg}\} \times \mathrm{Hc}$

Where:

$\mathrm{NSc}=$ Carbon sink value (IDR)

$\mathrm{Lg} \quad=$ Peat swamp forest (ha)

$\mathrm{Kcg}=$ Peat ability for carbon sink (Ton/Ha)

$\mathrm{Hc}=$ carbon price (IDR/Ton)
Option value $(\mathrm{OV})$

Option value benefit is benefit to preserve the use of goods, services and environmental resources in the future that cannot be used at present. In this study, the value which will be used is benefit of preservation for DSNP ecosystem biodiversity especially wildlife was approached by contingent valuation method to ask the willingness to pay or willingness to accept from respondents.

Table 1. Methods and kinds of economic value (modified from Barbier et al.1997)

\begin{tabular}{lll}
\hline \multicolumn{1}{c}{ Value } & \multicolumn{1}{c}{ Value that calculated } & \multicolumn{1}{c}{ Methods } \\
\hline Direct & Value of fish & Market price \\
value & Value of fuelwood & Opportunity cost \\
& Value of honey & Market price \\
& Value of rubber (garden) & Market price \\
& Value of rice (fields) & Market price \\
& Value of recreation & Travel cost \\
Indirect & Value of water for household & Water price \\
value & Value of water for transportation & Fuel price \\
& Value of water for fisheries & Market price \\
& Value of carbon sink & Market price \\
Option & Value of wildlife & Contingent valuation \\
value & & \\
\hline
\end{tabular}


The economic values were calculated based on market prices and other water consumption costs to be incurred based methods. The selection of a valuation technique depends on the characteristics of goods and services and the availability of information for each type. In reality this 'ideal' approach can rarely be followed completely. Often there is a lack of information. Some impact can be quantified reasonably well while others can only be estimated by order of magnitude. This research is intended to illustrate the intangible values from the ecosystem studied.

Total economic value (TEV) of DSNP obtained by summing all of the valuesmentioned above. Having obtained the TEV of potential DSNP, followed by analysis of the potential value of environmental services generated if there is a mechanism to make it areal value either through market mechanisms or government regulation.

\section{RESULTS AND DISCUSSION}

\section{Benefit of Danau Sentarum National Park ecosystem}

The benefits of DSNP by analyzing the characteristics of the ecosystem functions that are translated into a list of goods and services (De Groot et al. 2002). It is useful to look at and determine the availability of current and potential ecosystems in this ecological and biophysical context. Based on the function, as wetlands, the total economic value of the DSNP can be agreed to into 4 (four) functions, namely the regulatory function (value of carbon sink); carrier function (value from fish captured, honey, rubber, rice fields) production function (value of water for household, water for transportation, water for fisheries/aquaculture, fuelwood, recreation and tourism); and information function (option value). The distribution of each can be seen in Figure 2.

While the identification result showed that the benefits of DSNP consisted from direct, indirect and option value.

\section{Total economic value of Danau Sentarum National Park ecosystem}

The estimation of the total economic value is calculated by adding the economic value of the products or services provided by the DSNP environment. We obtain the TEV of the DSNP shown in Table 2.

The data in the table above shows that the economic value of carbon storage is very high (about 75.19 percent) compared to other economic values calculated. The result shows that the condition of the ecosystem DSNP is relatively good, has enough peat and is still awake. But on the other hand, suggests that the perception of the public, especially communities around the DSNP are still low on natural resources. Carbon storage is based on the perception of the world community and is a regulatory function of the ecosystem at large. The real and current value of the carbon storage is yet to be felt by the community, although it has great potential to be included in the environmental services market.

If carbon storage value is not included in the calculation, the total economic values of the DSNP can be seen in Table 3.

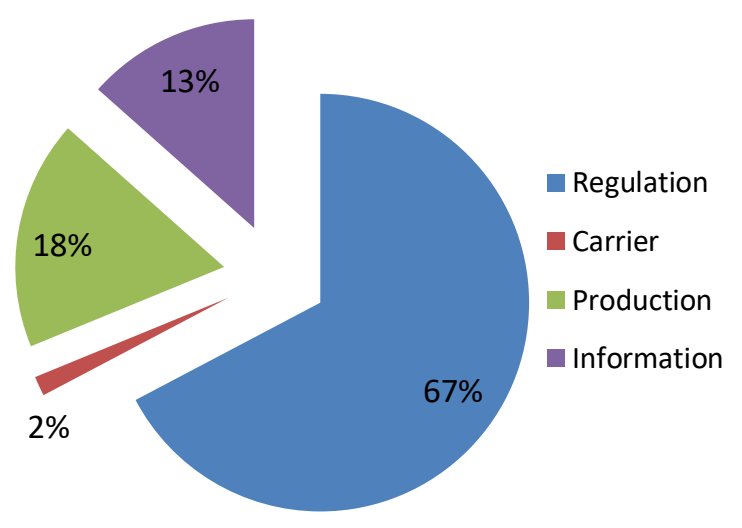

Figure 2. Economic value of the DSNP based on their function

Table 2. Total economic value DSNP

\begin{tabular}{llrr}
\hline \multirow{2}{*}{ Value } & \multicolumn{1}{c}{ Value that calculated } & $\begin{array}{c}\text { Economic valuation } \\
(\mathbf{R p} / \text { year })\end{array}$ & \multicolumn{2}{c}{ Economic valuation per ha } \\
\cline { 3 - 4 } (Rp/year)
\end{tabular}


Table 3. Total economic value DSNP without carbon storage value

\begin{tabular}{|c|c|c|c|c|}
\hline \multirow{2}{*}{ Value } & \multirow{2}{*}{ Value that calculated } & \multirow{2}{*}{$\begin{array}{c}\text { Economic valuation } \\
\text { (Rp/year) }\end{array}$} & \multicolumn{2}{|c|}{ Economic valuation per ha } \\
\hline & & & (Rp/year) & $\%$ \\
\hline \multirow[t]{6}{*}{ Direct value } & Fish & $15,505,805,000$ & $117,468.22$ & 11.15 \\
\hline & Honey & $729,630,000$ & $5,527.5$ & 0.52 \\
\hline & Rubber & $2,218,796,000$ & $16,809.06$ & 1.60 \\
\hline & Rice & $81,200,000$ & 615.15 & 0.06 \\
\hline & Firewood & $3,329,492$ & 25.22 & 0.00 \\
\hline & Recreation & $14,426,000$ & 109.29 & 0.01 \\
\hline \multirow[t]{3}{*}{ Indirect value } & Water for household & $964,476,000$ & $7,306.64$ & 0.69 \\
\hline & Water for transportation & $28,736,100,000$ & $217,697.73$ & 20.67 \\
\hline & Water for fisheries & $4,587,500,000$ & $34,753.79$ & 3.30 \\
\hline Option value & Option & $86,205,000,000$ & $653,068.18$ & 62.00 \\
\hline Total & & $139,067,307,492$ & $1,053,380.78$ & 100.00 \\
\hline
\end{tabular}

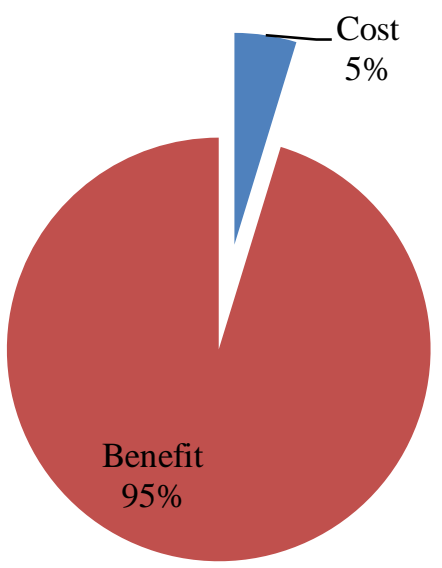

Figure 3. Cost and benefits management of DSNP

From the analysis of the potential economic value calculation, the total potential economic value of the DSNP ecosystem is IDR $139,067,307,492$ per year or IDR $1,053,380.78$ per ha per year. Table 3 shows that the highest benefit is from option value $(62,00 \%)$, followed by indirect value $(23,97 \%)$ and the lowest is direct value $(0,76 \%)$. The research result is rather different with another study that shows that indirect value has the highest value (Siregar 2012, Roslinda et al. 2014; Malik et al. 2015; Roslinda et al. 2018). It is because the research area is in the conservation area which contains high biodiversity to conserve.

The total economic value of the DSNP of IDR $139,067,307,492 /$ year or IDR 1,053,380.78/ha/year showed that the DSNP as a conservation area which has been considered as central expenditure (cost center) is not true. This can be proven by the amount of the management investment DSNP in 2010 which was IDR 6,768,844,000. When compared to the TEV of the DSNP, such costs amounted to only 4.87 percent compared to the value of the benefits (Figure 3 ).

\section{Possible mechanisms to finance ecosystem services provided by the DSNP}

An important point to deal with when implementing financing mechanisms is the equity aspect: the mechanisms chosen should not only benefit the park itself but also the small local communities in its surroundings. Based on Roslinda et al. (2018) that social capital of the community in the area of the DSNP is still strong, so local communities can be involved in financing mechanism in this area.

The typology of financing mechanisms is based on the degree of government intervention or public involvement in the administration of the mechanism (Powell et al. 2002; Landell-Mills and Porras 2002). They distinguished three indicative categories, including self-organized private deals or voluntary contractual arrangements, trading schemes, and public payment schemes. The IUCN (2000) and De Groot et al. (2007) proposed a classification of financing mechanisms based on the sources of finance: international sources of funding, national-level mechanisms and, sitelevel mechanisms. Local sources of funding include, among others, user fees, use of cause-related marketing and adoption programs, individual donations, and payment of public goods and services. Finally, it is possible to classify financing mechanisms according to the type of ecosystem service on which the mechanism is based (Verweij 2002). This paper chose as the entry point, the ecosystem services to be financed and explored and the possibilities of financing mechanisms based on the typologies developed by IUCN (2000) and Powell et al. (2002).

\section{Possible financing mechanisms for maintaining water supply}

The DSNP plays a significant role in maintaining and providing water supply services to PDAM West Kalimantan since all of these use the Kapuas River for water supply. Referring to the results of research done by Handayani (2008), the clean water supply services can be financed through a transfer payment. Transfer payment from downstream to upstream is given in the form of conservation funds which are included in the tariff taps for 
downstream communities. The amount of transfer payments obtained from the WTP is divided by the average monthly water use of each of the downstream communities. The magnitude of the WTP for Sintang community: IDR 34,297.08; Sanggau community: IDR 77,908.64 and Pontianak community: IDR 210,997.90.

\section{Possible financing mechanisms for maintaining recreation and tourism services}

Referring to Bernard et al. (2009), it is possible to develop financing mechanisms that involve tourism businesses and tourists visiting the DSNP. The hotels were willing to give direct donations or oblige tourists to pay more than IDR10,000 per night, in order to ensure the preservation of national park. Therefore the national park visitor is willing to pay for services and/or to contribute to the national park sustainability and uniqueness.

\section{Possible financing mechanism involving oil palm plantations}

Around the DSNP, there are 18 palm oil plantations (WWF 2007). In order to preserve the DSNP environmental services should include payments for compensation. This compensation is responsible for the preservation of the estate as DSNP. For example, upon its creation, a plantation will pay about IDR100,000,000/year to the park administration as will the 18 other plantation companies to support financing national park. Following the example, the potential payments to be made by other companies would equal IDR 1,8 billion. The advantage of the instrument is the amount of company donations if different stakeholders were to reach an agreement. Moreover, the mechanism could be implemented immediately. However, it usually takes time and a long process to set up a meeting with the company and the reliability of the mechanism is dependent on the willingness of the companies involved. Actually, if there is good faith from the government as the owner of the authority of the permit, this mechanism could likely succeed.

In conclusion, the benefits of DSNP ecosystems identified consist of direct benefits (fish, honey, rubber, rice, and recreation); indirect benefits (water for household, water for transportation, water for fisheries and carbon sink) and options benefit of wildlife values. Total potential economic value of DSNP is IDR139,067,307,492/year or IDR $1,053,380.78 / \mathrm{ha} /$ year. The highest benefit is from option value $(62.00 \%)$, followed by indirect value $(23.97 \%)$ and the lowest is direct value $(0.76 \%)$. Economic valuation has proved to be a strong and useful tool in the analysis of national park financing change and sustainable use. This research explored the possibility of developing new financing mechanisms to increase and secure financial support for the Danau Sentarum National Park. The total value of the DSNP is IDR 139,1 billion/year, equivalent to an average of IDR 1,1 million/year for the total park area $(132,000$ ha), which would be just sufficient to cover the funds needed for sustainable park management (IDR 6,768 million/year). In the short term, the most promising financing mechanisms seem to be individual donations from water users, while from visitors and oil palm plantation could be considered as part of a long term financing strategy. The development and implementation of the financing mechanisms can lead to high transaction cost that should be identified prior to their implementation and should be limited to ensure the effectiveness of the financial mechanisms. It means there is integrating the ecological and economic dimensions in biodiversity (De Groot et al. 2010) . Local communities should be involved in the provision and maintenance of the ecosystem services provided by parks and share in the benefits, to ensure their effective and sustainable conservation.

\section{ACKNOWLEDGEMENTS}

We would like to thank people of the DSNP Kapuas Hulu, West Kalimantan, Indonesia for their open hearts and support of our work. Moreover, we are thankful to the Directorate General of Higher Education for the funding for this research through the competitive research grant scheme, Tanjungpura University, Balai Taman Nasional Danau Sentarum, Kapuas Hulu District Government for facilities and works. Great thanks to other parties who cannot be mentioned personally for giving us their help to accomplish this work.

\section{REFERENCES}

Aglionby J. 2010. Danau Sentarum National Park, Indonesia: historical overview. http://www.thefreelibrary.com/2.+danau+sentarum+ national+park\%2c+indonesia\%3a+a+historical+overview.-0254265420

Bernard F, De Groot RS, Campos JJ. 2009. Valuation of tropical forest services and mechanisms to finance their conservation and sustainable use: A case study of Tapanti National Park, Costa Rica. For Pol Econ 11: 174-183.

Colfer CJP, Salim A, Wadley RL. 2000. Understanding patterns of resource use and consumption: A prelude to co-management. Borneo Res Bull 31: 29-88.

Darusman D. 2012. Forestry for sustainable Indonesia. IPB Press, Bogor.

De Groot RS, de Wit M, Gaddis EJB, Kousky C, McGhee W, Young MD. 2007.Making restoration work: financial incentives. In: Aronson, James, Milton, Suzanne J, Blignaut, James N, editors. Restoring Natural Capital: Science, Business and Practice. Island Press, Washington D.C.

De Groot RS, Fisher B, Christie M, Aronson J, Braat L, Haines-Young R, Gowdy J, Maltby E, Neuville A, Polasky S, Portela R, Ring I. 2010. Integrating the ecological and economic dimensions in biodiversity and ecosystem service valuation. In: Kumar $P$ (ed.). TEEB Foundations, The Economics of Ecosystems and Biodiversity: Ecologicaland Economic Foundations. Earthscan, London.

De Groot RS, Wilson M, Boumans R. 2002. A typology for the description, classification and valuation of ecosystem services, goods and services. In: The dynamics and value of ecosystem services: Integrating economic and ecological perspectives. Ecol Econ 41 (3): 393-408.

DSNP [Danau Sentarum National Park]. 2011. Statistical Data 2010. Danau Sentarum National Park, Sintang. [Indonesian]

Dudley RG. 2000. The Fishery of Danau Sentarum. Borneo Res Bull 31: 261-306.

Fauzi A. 2004. Economy of Natural resources and Environments. Gramedia, Jakarta.

Frazier S. 2000. Crocodiles of Danau Sentarum. Borneo Res Bull 31: 307322.

Giesen W. 1987. Danau Sentarum Wildlife Reserve: Inventory, ecology and management. Report commissioned by World Wildlife Fund for Nature. WWF Zeist, Netherlands. 
Giesen W. 2000. Flora and vegetation of Danau Sentarum: Unique lake and swamp forest ecosystem of West Kalimantan. Borneo Res Bull 31: $89-122$.

Giesen, W. and Aglionby J. 2000. Introduction to Danau Sentarum National Park, West Kalimantan. Borneo Res Bull 31: 5-28.

Handayani NW. 2008. Valuasi ekonomi dan mekanisme insentif Taman Nasional Danau Sentarum. [Thesis]. Universitas Indonesia, Depok. [Indonesian]

Harahap N. 2010. Economic valuation of mangrove ecosystem and its application in coastal area planning. Graha Ilmu, Yogyakarta. [Indonesian]

Harwell E. 1997. Law and culture in resource management: An analysis of local systems for resource management in the Danau Sentarum wildlife reserve, West Kalimantan, Indonesia. Wetlands International, Bogor.

Heri V, Yuliani EL, Indriatmoko Y. 2010. Interacting threats and challenges in protecting Danau Sentarum. Borneo Res Bull 41 :74100 .

Indriatmoko Y. 2010. Rapid human population growth and its impacts on Danau Sentarum. Borneo Res Bull 41 :101-108.

IUCN. World Commission on Protected Areas. 2000. Financing protected areas. In: Philips A, editor. Guidelines for protected area managers Best Practice Protected area Guidelines. Vol 5. IUCN, London, UK \& Gland, Switzerland.

Klepper O. 1994 A Hydrological model of the upper Kapuas River and the Kapuas Lakes. Consultancy Report for the Asian Wetland Bureau / PHPA for the UK-Indonesia Tropical Forestry Management Programme, Bogor.

Kottelat M. Widjanarti E. 2005. The fishes of Danau Sentarum National Park and the Kapuas Lakes area, Kalimantan Barat, Indonesia. Raffles Bull Zool 13: 139-173.

Kumar M, Kumar P. 2008. Valuation of the ecosystem services: A psycho-cultural perspective. Ecol Econ 64 (4): 808-819

Landell-Mills N, Porras IT. 2002. Silver Bullet or Fool's Gold? A Global Review of Markets for Environmental Services and their Impact on the Poor. IIED, London.

Malik A, Fenshol R, Mertz O. 2015.Economic valuation of mangroves for comparison with commercial aquaculture in South Sulawesi, Indonesia. Forest 6: 3028-3044

Powell L, White A, Landell-Mills N. 2002. Developing Markets for the Ecosystem Services of Forests. Forest Trends, Washington DC., US.
Roslinda E, Kartikawati SM, Rabudin. 2017. Economic valuation for tembawang ecosystem, in Sanggau District, West Kalimantan, Indonesia. Biodiversitas 19 (4): 1249-1257.

Roslinda E, Yuliantini. 2014. The economic value of hydrological services in Mendalam sub-watershed, Kapuas Hulu regency, West Kalimantan, Indonesia. Indon J For Res 1: 1-8.

Roslinda E. 2016. Dayak Desa forest land use system as social capital to acquire management rights in West Kalimantan, Indonesia. Biodiversitas 17 (1): 177-184

Roslinda E. 2018. Social capital of the community in the management Danau Sentarum National Park West Kalimantan, Indonesia. Biodiversitas 18 (4): 1506-1516

Russon A, Meijaard E, Dennis R. 2001. The population and distribution of Orangutans (Pongo pygmaeus) in and around the Danau Sentarum wildlife reserve, West Kalimantan, Indonesia. Biol Conserv 97: 2128 .

Sebastian AC, Dennis R. 2000. Proboscis monkeys in Danau Sentarum national park. Borneo Res Bull 31: 359-371.

Siregar AF. 2012. Economic valuation and conservation strategic analysis of mangrove forest in Kubu Raya District. [Thesis]. Bogor Agricultural University, Bogor. [Indonesian]

van Balen B, Dennis R. 2000. Birds of Danau Sentarum. Borneo Res Bull 31: 336-358.

Verweij P. 2002. Innovative financing mechanisms for conservation and sustainable management of tropical forests. Issues and perspectives. Understanding and capturing the multiples values of tropical forest. Proceedings of the International Seminar on Valuation and Innovative Financing Mechanisms in Support of Conservation and Sustainable Management of Tropical Forest. Tropenbos International, Wageningen.

Wadley RL, Colfer CJP, Dennis R, Aglionby J. 2010. The social life of conservation: Lesson from Danau Sentarum. Ecol Soc 15 (4): 39. http: //www.ecologyandsociety.org/vol15/iss4/art39/

Wadley RL. 1997. Circular labor migration and subsistence agriculture: a case of the Iban in West Kalimantan, Indonesia. [Dissertation]. Arizona State University, Tempe, AZ.

Walter, O. 2000 A study of hunting and trade of freshwater turtles and tortoises. Borneo Res Bull 31: 323-335.

WWF-Indonesia. 2007. Profit Heart of Borneo. WWF-Indonesia, Jakarta.

Yasmi Y, Colfer CJP. 2010. Forestry and fishery in Danau Sentarum: application of an impairment approach. Borneo Res Bull 41: 145-161. 